\title{
EFFECT OF CORPORATE INCOME TAX AND MARKETIZATION DEGREE ON CAPITAL STRUCTURE OF CHINESE LISTED COMPANIES
}

\begin{abstract}
Using the 2008 corporate income tax reform as an opportunity, this paper constructs a Panel DID model to study the effect of corporate income tax and the degree of marketization on capital structure. Based on the 2008 Enterprise Income Tax Reform in China, accompanying with both rise and fall in the tax rate, the paper tests the adaptability of the Modigliani \& Miller theory, and develops a capital structure theory in the context of China. Author's used the financial data of 206 Chinese listed companies from 2002 to 2012. The financial data of listed companies were mainly taken from Xenophon database and GuoTaian database. The marketization index data were obtained from The Marketization Index in China: 2011 Report for the Relative Marketization Process in Various Regions. Industries was classified according to the Global Industry Classification Standard (GICS) and test the sensitivity of the capital structure to exogenous corporate tax rate change in different industries. The empirical results show that: firstly, the higher the degree of marketization is, the more significant the tax shield effect is; secondly, compared to the corporate income tax, differences in the degree of marketization exert a more significant effect on the corporate capital structure; thirdly, because of the long existence of tax incentives, debt tax shield is not significant in people's livelihood industries and information technology industry; Fourthly, given the upward trend in the overall asset-liability ratio of Chinese companies, in order to control companies' financial risk, we recommend to foster market reform and the use corporate income tax incentives where necessary. The results of research will provide a reference for future marketization reform and tax policies in different industries in China.
\end{abstract}

KEYWORDS: Corporate income tax, corporate income tax reform, marketization, capital structure.

Юн Фань

Центральный Университет Финансов и Экономики,

г. Пекин, Китай

\section{ВАИЯНИЕ КОРПОРАТИВНОГО НАЛОГА НА ПРИБЫАЬ И УРОВНЯ МАРКЕТИЗАЦИИ НА СТРУКТУРУ КАПИТААА ПУБАИЧНЫХ КОМПАНИЙ КИТАЯ}

\begin{abstract}
АННОТАЦИЯ. В статье анализируются данные об изменении структуры капитала компаний в связи с реформой корпоративного налога на прибыль, акции которых обращаются на бирже. Изучается влияние степени маркетизации экономики в регионах на структуру капитала компаний, расположенных в них. Реформа налога на прибыль проводилась в 2008 г., ее результатом должно было стать постепенное (в течение 5 лет) снижение налога для большинства компаний с 33 до 25 \%, а также повышение налога для части компаний с 15 до 25 \%. Анализ изменения структуры капитала компаний вследствие повышения (понижения) налога на прибыль позволил подтвердить применимость теоремы МодильяниМиллера и развить теорию структуры капитала применительно к условиям Китая. Для анализа использовались данные о структуре капитала 206 компаний, акции которых обращались на бирже в 2002-2006 и 2008-2011 гг. В выборку попали 75 компаний, у которых эффективная ставка налогов увеличилась, и 131 компания, у которых она снизилась. Информация о их финансовых результатах была получена из баз данных Xenophon и Guotai. Результаты анализа подтвер-
\end{abstract}


дили гипотезу о том, что степень рыночности экономики и изменение налога на прибыль влияют на структуру капитала, что позволило сделать следующие выводы: во-первых, повышение степени маркетизации, увеличивает экономию на налоговых выплатах, возникающую при реструктуризации капитала компании; во-вторых, рост степени маркетизации региона, увеличивая экономию на налоговых выплатах приводит к росту радикальных вариантов налогового планирования, используемых публичными компаниями; в-третьих, по сравнению с изменением ставки налога на прибыль, степень маркетизации оказывает более существенное влияние на структуру корпоративного капитала; в-четвертых, изза долгосрочного существования налоговых льгот, экономия на налоговых выплатах не имеет большого значения в отраслях производства потребительских товаров, здравоохранении и информационных технологиях. Отношение активов к пассивам китайских публичных компаний имеет тенденцию к увеличению, что, с одной стороны, отражает рост эффективности использования финансовых рычагов, а с другой - повышает операционные риски. Следовательно, в целях контроля финансовых рисков компаний необходимо стимулировать рыночные реформы и по возможности использовать льготы по налогу на прибыль.

КЛЮЧЕВЫЕ СЛОВА: налог на прибыль корпораций, реформирование налога на прибыль корпораций, маркетизация, структура капитала.

\section{Introduction}

Capital structure, also known as the financing structure, is the value of composition and proportion relation of the long-term debt capital and equity capital. Differences in capital structures reflect the diversities in financial leverage and operating risk. For a long time, due to the strict approval process of bank loans, the relatively underdeveloped bond market and firms' preference in equity financing, the average asset-liability ratio of listed companies in China is lower than that of those listed in the more matured market in developed countries. In recent years, Chinese enterprises' asset-liability ratio rose from $48,76 \%$ in 1993 to $86,76 \%$ in 2010, and the uneven distribution among regions and industries is being exacerbated. In 2010, for example, the ratio of Beijing $(90,29 \%)$, the highest one, was around 1,93 times of that of Shaanxi $(46,72 \%)$, the lowest one. The ratio of the financing and insurance industries $(93,49 \%)$, the highest one, was 2,49 times of the ratio of the media and cultural industries $(37,57 \%)$, the lowest one ${ }^{1}$. However, the debt ratio should not be too high or too low, or it will be harmful to the corporate capital structure, and thus

Statistical Yearbook of the China Securities and Futures / China Securities Regulatory Commission, Xuelin Press, 2011. negatively affect the competitiveness and sustained development of enterprises.

Among all external factors that affect the capital structure, income tax burden has been widely acknowledged as one of the most important factors. Modigliani \& Miller [1] who proposed the famous MM corporate tax model believe that, in the existence of corporate income tax, liabilities will increase corporate value as the interest reduces the tax. For investors, that means more distributable operating revenue. Many Chinese scholars have studied the adaptability of the theory in China. However, these studies fail to consider the institutional environment properly. The corporate income tax reform in 2008 reduced most of the corporations' tax rate from $33 \%$ to $25 \%$. At the same time, the tax rate for those whose previous rate was $15 \%$ would be gradually increased to $25 \%$ in a span of 5 years. The reform, accompanying with both rise and fall in the tax rate, not only provides an excellent sample to test the adaptability of the MM theory, but also supplies a good opportunity to develop a capital structure theory that fits the context in China. Another external factor that significantly affects the corporate capital structure is the degree of marketization in the region where the corporation is located. As Myers (2003) stated, the institutional arrangements and financial 
markets in different countries may present core varieties, resulting in the fact that the theory of capital structure cannot be simply applied to other countries. In China's process of transiting toward market economy, the boundaries between government and market are blurred, and thus the corporate finance behaviors are irrational and distorted. In the context of contemporary situation in China, it is really worthy to study the impact of the changes in corporate income taxes and the degree of marketization on firms' leverage decisions.

\section{Literature Review}

Modigliani \& Miller [1] put forward the corporate tax MM Theorem, namely the debt tax shield: as debt interests are tax deductible expenses and, thus, reduce the income tax expense, the optimal leverage should be $100 \%$. Therefore, when the corporate income tax rate changes exogenously, firms are motivated to adjust their capital structure to maximize the value of the tax shield. The Miller model of the corporate income tax [2] also indicates that the higher the corporate income tax rate is or the larger the debt size is, the greater the value of the debt tax shield is, and the more likely firms are prone to debt financing. Apparently, these theories cannot explain firms' financing behavior perfectly, because the assumptions underlying the theories are very strict. Thereafter, in terms of the capital structure researchers try to release the assumptions. Two schools came into existence: the tax differential school (Farrar, 1967; Brennan, 1978) and the financial distress school (Altman, 1968; Betker, 1978). These two schools were later combined into the trade-off theory with the representative of Robichek (1967), Myers (1984), Scott (1976), and so on. According to the trade-off theory, the optimal capital structure is the balance point between the tax benefit of debt financing and the cost of bankruptcy. Since the 1970s, with the development of information asymmetry theories, new capital structure theories appear, such as the financial pecking order theory Myers [3], the agency cost theory (Jensen \&
Mecking, 1976; Stulz, 1990; Dewatripont \& Tirole, 1994) and the signal theory (Ross, Leland \& Pyle, 1977). The new theories laid more focus on subjective factors like corporate governance and information conduction. While the traditional MM theorem constructs the foundation for studies on tax shield effects, the trade-off theory and the financing pecking order theory are important references when we are constructing the regression analysis model. Previous research studies on the relationship between debt tax shields and capital structure usually control the size of the company, profitability, growth opportunities, asset structure, governance structure, etc. However, the results are contradictory. Davis (1987), Fischer, Heinkel \& Zechner (1989) and Xia Li (2008), etc. conclude that the debt tax shield effect is not significant or weakly significant. On the contrary, Mackie-Mason [4], Givoly, Hayn, Ofer, Sarig [5], Genfu Feng (2000) and Zhiqiang Wang (2003) find that the debt tax shield and debt ratio are significantly and positively correlated. Some researchers believe that the external environment may be an important reason for the contradictory conclusions in the study on capital structure (Rajan \& Zingales [6]; Booth, et al, 2001; Fan et al, 2010). In China, the degree of marketization is a nonignorable institutional factor in the study of firm's leverage decisions. Jie Zhang (2000), Junxiong Fang [7], and Wei Jiang \& Bin Li [8], in terms of the nature of property rights, find that state-owned enterprises get more loans with longer terms than non-state-owned enterprises. From the perspective of political connections, Justin Lin and Li Zhi Chan (2004), Jianhua Guo and Xingqiang Du (2011) find that, while political connections bring more debt financing to the enterprises, they also bring heavier policy burden to the enterprises. From the perspective of law and finance, Minggui Yu and Hongbo Pan [9] conclude that the more effective the regional legal system and finance system, the less loans enterprises are granted and the shorter the loans' terms are. They attribute this fact to the local government's intervention on banks' loan policies. These research 
studies select a particular aspect of the marketization process (such as the nature of property rights) and study its effect on capital structure, in the context of «soft budget constraint $»^{2}$. So far, there are only two research works that study the impacts of marketization, as a whole, on capital structure. Zheng Sun, Fengwei Liu and Zengquan Li [12] use panel data and find that the higher the degree of marketization in the region where the company is located is, the lower the proportion of long-term debt is. Fuxiu Jiang and Jicheng Huang [13] find that the faster the degree of marketization increases, the faster the capital structure adjustment is, and the lower the degree of deviation from the target capital structure is. However, both studies have neglected the impact of debt tax shield on capital structure. As Miller said, the tax is always a unique factor in finance. Missing them will result in biased estimates.

We find that most of above research works do not take into account the 2008 corporate income tax reform, which is an important policy change (for example, Xiaoyue Chen \& ChenLi, 1995; Zhengfei Lu \& Yu Xin, 1998; Xixi Hong \& Yifeng Shen, 2000; Changjiang Lv \& Kemin Wang, 2002). Yuetang Wang, Liang liang Wang and Yang Peng [14] is the single research that relates the 2008 reform with the capital structure. They study the relations among the nature of property rights, debt tax shield and capital structure. They find that state-owned property rights and nonstate-owned property rights exert different effects on the debt tax shield. Unfortunately, Yuetang Wang et al only select data in 2006

The «soft budget constraint» is put forward by Kornai [10]. It refers to the fact that, under political intervention, creditors are unable to enforce firms to do bankruptcy liquidation when they fail to pay principals and interests on time. In that case, firms' budget constraints are soft. Yifu Lin et al [11] and Tao Li (2004) demonstrate the existence of «soft budget constraint». The «hard budget constraint» refers to the fact that when the enterprise fails to pay principals and interests on time, creditors can exert control rights on managers, which constrains the operation of the firms to some extent (Grossman \& Hart, 1982). In their empirical research, Lang, Ofek\&Stulz (1996) found that debt financing can reduce improper investment and improve the efficiency of operation. and 2008 to conduct multiple regression analysis. They ignore the heterogeneous factors caused by the time variation and the lag effect of corporate financing decisions on the exogenous tax rate change. According to Fang Wang (1999) and Yanming Wang [15], changes in capital structure are mainly influenced by the actual effective tax rate (ETR). Even so, Yuetang Wang et al still use the change of statutory tax rate (MTR) as the dummy variable of tax rate change. Moreover, like the other researchers, they control the industry effect, but fail to reveal the industry effect caused by the impact of debt tax shield on asset structure.

Yuhan Chen (2005) uses 680 A-share listed company's financial data as a sample and find apparent potential tax shield effect in most companies, showing that further debt financing is feasible. Dengta Chen et al (2011) use a yield curve model for marginal debt tax shield, and conclude that Chinese listed companies are conservative in leverage decisions. As a result, the value of debt tax shield they can acquire is low, and the space for further debt financing is big. In regard of the background that Chinese listed companies use financial leverage insufficiently and thus gain less benefits from tax shield effect than the listed companies in developed countries, will the corporate capital structure be influenced by the 2008 corporate income tax reform and the different degree of marketization among different regions across the country? And will the influence be the same in different industries? Taking the opportunity of the 2008 corporate income tax reform, we use the financial data of Chinese listed companies from 2002 to 2012 and apply the effective tax rate (ETR) theory and panel data mixed effects model to reveal the impact of the marketization and corporate income tax on the capital structure. In addition, we classify industries according to the Global Industry Classification Standard (GICS) and test the sensitivity of the capital structure to exogenous corporate tax rate change in different industries. We hope our research will provide a reference 
for future marketization reform and tax policies in different industries

\section{Research Design}

\section{Theoretical Assumptions.}

1.1. Debt Tax Shield. As a result of the 2008 corporate income tax reform, nearly all Chinese enterprises experienced one of the two types of tax rate change:

- enterprises whose original tax rate was $33 \%$ now enjoy a reduced tax rate of $25 \%$;

- enterprises whose original tax rate was $15 \%$ now suffer an increased tax rate of $25 \%$.

The later group are mainly foreigninvested enterprises, as well as those who enjoyed industrial or regional beneficial tax rate. Changes in statutory tax rate would certainly affect the effective tax rate. According to $\mathrm{MM}$ theorem and the «Differential Taxation Hypothesis», since debt interests are tax deductible expenses, decrease (increase) in the effective tax rate will result in the fall (rise) of the value of the debt tax shield. This will accordingly reduce firms' enthusiasm to borrow capital and make financial leverage lower (higher) than it was before the reform. In addition, taking into account the fact that the assetliability ratio of Chinese enterprises has long been lower than that of enterprises in developed countries, if the efficiency of operation is improved, firms' ability to use financial leverage will be further enhanced.

Hypothesis 1 . After the 2008 corporate income tax reform, companies whose effective income tax rates (ETR) are increased will enhance their financial leverage, while companies whose effective income tax rates are decreased will reduce their financial leverage.

Hypothesis 2. With the increase in firms' ability to use leverage, their assetliability ratios are rising gradually.

2. Marketization. Current research studies show that, in the context of imperfect market system, banks' lending behavior becomes irrational and distorted (Demirgu-Kunt \& Maksimovic, 1999; Giannetti, 2003). Chinese banks are always willing to provide more debt financing to the state-owned listed companies. As a result, state-owned companies keep excessive debt while non-state-owned companies suffer difficulties in debt financing. This fact makes the capital allocation in the market deviated from the optimal result. Therefore, in the regions where the government and enterprises are closely related, and the degree of marketization is relatively low, the «soft budget constraint» exists and companies do not have strong incentive to adjust their capital structure to respond to exogenous tax rate changes. On the contrary, in the regions where there is less governmental intervention and the development of the market is sound, companies' competition is intensive. Leverage governance is widespread. Thus, listed companies in these regions are more sensitive to exogenous tax rate changes.

Hypothesis 3. The higher the degree of regional marketization, the more sensitive the listed companies in that jurisdiction are to exogenous tax rate changes and the more radical and the greater their capital structure adjustments are.

1.3. Industry Effect. Ferri \& Jones (1979) believe that, since firms in the same industry rely on similar technology and face similar costs in raw materials and labor their business risks and assetliability ratios are similar. Many other research works also find a significant difference in the capital structure of firms in different industries (Belkakoui, 1975; Errunza, 1979; Aggarwal, 1990; Juan, Yang Fenglin, 2002; Guo Pengfei SUN Pei-yuan, 2003). In China, due to the prevalence of tax incentives concerning tax rates, tax base, etc., many firms' effective tax rates are lower than their statutory tax rates. Therefore, the debt tax shield effect is limited.

Hypothesis 4. In industries (such as industries concerning public well-being and high-tech industry) where there are many tax incentive policies, the debt tax shield effect is negligible.

\section{Sample and data source}

2.1. Sample Period. Thenew tax law was passed in 2007. Since it was not effective this year, the new tax rate and other provisions 
should not have a material influence on the related firms. However, research works show that the listed companies with tax reduction expectations had already conducted earnings management to avoid tax in that year. Therefore, we exclude the 2007 data because they blend the effects before and after the reform. To compare the impact of the debt tax shield on the capital structure before and after the tax reform, we divide the sample into two observation periods: period before the reform and period after the reform. Period before the reform is identified as the control period. We select the period of 2003-2006 as the control period for two reasons. First, according to the Document No. 99 (2000) issued by Chinese Ministry of Finance, A Notice on Seriously Implementing the State Department's Document «A Notice on Correcting Local Governments' Collect-and-Return Tax Policy», all «collect-and-return» preferential taxation policies to listed companies should be ended by January 1, 2002. Second, some variable index needs to use first-order lag data. We select the period of 2008-2011 as the sample period after the reform.

2.2. Sample Screening. By the end of 2010, were 2114 listed companies in Chinese A-share market. On this base, we conduct the following screening process:

- eliminate 36 financial insurance companies;

- eliminate 886 companies who did their IPOs after 2002;

- eliminate 416 companies whose shares were trade-abnormal during 20022011, including ST companies, companies whose shares were suspended for listing and companies delisted;

- eliminate 404 companies which reported negative pretax income or income tax expense ${ }^{3}$ in 2002 to 2011;

- eliminate 84 companies who changed either their GICS industry classifications or registered address;

\footnotetext{
3 Cordes \& Sheffrin (1981) and Mackie-Mason (1980) thought if a company's taxable income is non-positive, its marginal tax rate for debt interest deduction is zero, so the company is in a situation of Tax Exhausted, which means additional debt can't be tax deductible and the company lacks the tax incentives to increase debt.
}

- eliminate 82 companies where the required financial data is not complete or is abnormal.

The final sample consists of 206 listed companies (Table 1). Among them, 75 sample companies experienced an increase in their effective tax rate in 2002-2006 and 2008-2011, while 131 companies enjoyed a reduction in the same periods. The financial data of listed companies were mainly taken from Xenophon database and GuoTaian database. The marketization index data were obtained from The Marketization Index in China: 2011 Report for the Relative Marketization Process in Various Regions.

Table 1

\section{Sample Screening Process and Number} of Samples

\begin{tabular}{|l|c|}
\hline $\begin{array}{l}\text { A-share listed companies (by the } \\
\text { end of 2010) }\end{array}$ & 2014 \\
\hline Finance and insurance firms & 36 \\
\hline IPO after 2002 & 886 \\
\hline $\begin{array}{l}\text { ST, Suspended for listing and } \\
\text { delisted }\end{array}$ & 416 \\
\hline $\begin{array}{l}\text { Negative pretax income or income } \\
\text { tax expense }\end{array}$ & 404 \\
\hline GICS industry classification changes & 84 \\
\hline Registered address changes & 2 \\
\hline $\begin{array}{l}\text { Financial data not complete or } \\
\text { abnormal }\end{array}$ & 82 \\
\hline Final Samples & 206 \\
\hline
\end{tabular}

\section{Model \& Variables.}

The panel data estimation model has three types of effects: a mixed effect, a random effect and a fixed effect. Based on the nature of our samples, we choose the mixed effect model for regression analysis:

$$
\begin{aligned}
& D A R=\beta_{0}+\beta_{1} E T R+\beta_{2} S I Z E+ \\
& +\beta_{3} R O A+\beta_{4} Z+\beta_{5} C A S H+ \\
& +\beta_{6} U N I Q+\sum \beta_{i} I N D_{i}+\varepsilon ;
\end{aligned}
$$

$$
\begin{aligned}
& D A R=\beta_{0}+\beta_{1} E T R+\beta_{2} D O M+ \\
& +\beta_{3} E T R \cdot D O M+\beta_{4} S I Z E+ \\
& +\beta_{5} R O A+\beta_{6} Z+\beta_{7} C A S H \beta_{8} U N I Q+ \\
& +\sum \beta_{i} I N D_{i}+\varepsilon .
\end{aligned}
$$


DAR is the variable to be explained. It is the asset liability ratio, a measure of firm's leverage (i. e., capital structure). $\mathrm{DAR}=$ total liabilities/total assets. There is no consensus on the measurement of firm's leverage. Early empirical researchers usually used total liabilities to compute the leverage, such as Fisher, Heinkel \& Zechner (1989). However, Taub (1975) and Kane, Marcus \& McDonald (1984) used the ratio of total liabilities to shareholders' equity. The former believed that both computations were similar in their rationality and could be converted to each other. But EINaggar (1996) pointed out that total liabilities contained non-interest debts which couldn't provide tax shields to the firms. Therefore, the use of interest-bearing liabilities would be more accurate. We use the asset-liability ratio because of the nonavailability and incompleteness of data.

ETR is a dummy variable for the effective tax rate. In 2008, the enterprise income tax reform caused the change in statutory rates. However, firm's capital structure is mainly influenced by the effective tax rate. Besides, many listed companies use different statutory rates in parent and subsidiary companies. So, we refer to Porcano (1986), and calculate ETR in the form: ETR = income tax expense/ EBIT. After eliminating the mixed effect of the data in 2007 and annual anomaly values $($ ETR $>1)$, we calculated respectively the average effective tax rate in 2002-2006 and 2008-2011. ETR is 1 if ETR 2008-2011 $_{2}<$ ETR $_{2002-2006,}$ meaning the effective tax rate is reduced. ETR is 0 otherwise. According to Hypothesis 1 , compared to the companies whose effective tax rates have increased, companies whose effective tax rates have decreased will obvious compress their debt size. So, we expected $\mathrm{ETR}^{4}$ coefficient to be negative. As we can see

\footnotetext{
${ }^{4}$ There are four popular methods to compute ETR: ETR = ITE (Income Tax Expense) / EBIT, (Porcano, 1986); ETR $=$ ITE $/($ Pretax Profit - ITE $/$ STR $) ;($ Procano, 1986); $\mathrm{ETR}=(\mathrm{ITE}-$ Deferred Income Tax Liabilities $) /$ EBIT, (Stickney \& McGee, 1982); ETR = (ITE - Deferred Income Tax Liabilities) / (Pretax Profit - ITE / STR), (Shevlin, 1987). Chinese listed companies used either Tax Payable Method or Tax Effect Method to account for income tax. Most companies used the Tax Effect Method, which led to very low deferred tax balance. In this case, we use the first ETR calculation method and do not consider the adjustment of deferred income tax liability.
}

(Table 2), from period 2002-2006 to period 2008-2011, the number of companies whose original tax rate fell in 0-10\%, 10-20\% and 20-30\% intervals increased, but the number of companies with more than $30 \%$ original tax rates declined obviously. This fact shows that the reform did reduce firms' taxes.

Based on Model (A), Model (B) joins a dummy variable (DOM) for the degree of marketization. Marketization index refers to a comprehensive index which reflects the following situations in a specific region: relationship of local government and market, development of non-stateowned economy, product market, element market and market intermediary organizations, and the legal environment. If the sample company is registered in the province with higher degree of marketization, DOM is Otherwise, DOM is 0 . Similar to the dummy variable ETR * YEAR for the effect of the reform, ETR * DOM is the product of the tax rate change and marketization degree. If a company's effective tax rate decreases and the company is registered in a province with high degree of marketization, the cross-term is 1 . Otherwise, it is 0 . We rank the provinces according to their average degree of marketization in 1997-2009. The top ten are specified as the region with higher degree of marketization. All the other provinces are specified as the regions with lower degree of marketization. Zhejiang province ranked the first. The top ten just included the four municipalities directly administered by the central government and all coastal provinces except Guangxi and Hainan provinces. Table 3 presents the degree of marketization for all provinces.

The other variables in the models are control variables. They are explained in the following paragraphs.

SIZE is the scale of a company. It is defined as the natural logarithm of total assets' carrying value at the end of each year. Many works (Taggart, 1977; Titman, Sheridan \& Wessels [16]; Wald, 1999; Rajan \& Zingales, [6] argue that the scale is a reverse proxy variable of bankruptcy probability. Large companies have more debts than small companies. 
Zhengfei Lu, Yu Xin (1998) proposed that big companies have the ability to diversify their operations or integrate their operations vertically, which makes their income more stable and enables them to keep more debts. After a study of 230 security issuances by 129 enterprises in 1950-1965, Baxter \& Cragg (1970) found that the greater the scale of an enterprise was, the more it was prone to raise capital by issuing bonds (or by issuing various securities including preferred stock, convertible securities, and bonds). Therefore, we expect the SIZE coefficient to be positive.

ROA represents profitability. It is computed as the ratio of the net income and total assets, i. e., return on assets. Proxy variables available for profitability include return on equity, operating profit and marginal profit, etc. We choose ROA to ensure that the index calculation does not involve liabilities. According to the financing optimal sequence theory proposed by Myers [3], the stronger a firm's profitability is, the more it is prone to conduct the lower cost internal financing instead of external financing. So, firms with high profitability will significantly reduce the level of debts. Timan \& Wessels [16], Friend and Lang (1988) and Rajan \& Zingales [6] also founded that profitability and financial leverage have negative correlation. We expect the sign of ROA to be negative.

Bankruptcy risk $Z$, computed as an amendment of $Z$ value which measures a firm's possibility of bankruptcy each year. $Z$ value (1968) was proposed by Altman. Graham [17] and Cbryanetal (2003) revised Altman's $Z$ value. The revised $Z$ value is computed as: $Z=$ total assets $/(3,3 *$ profit before interest and tax + sales revenue + 1,4 * retained earnings $+1,2$ * net working capital). Liability results in a financial cost of paying the interest regularly and repaying principal when due. The revised $Z$ value can be used to measure this cost. The smaller the value is, the better the firm's overall financial condition is, and the smaller the possibility of bankruptcy is. Thus, the firm is able to obtain more

ETR Distribution

\begin{tabular}{|c|c|c|c|c|c|}
\hline \multirow[b]{2}{*}{$\begin{array}{c}\text { ETR } \\
\text { Distribution }\end{array}$} & \multicolumn{2}{|c|}{$2002-2006$} & \multicolumn{2}{|c|}{$2008-2011$} & \multirow{2}{*}{$\begin{array}{l}\text { Percentage } \\
\text { Change, \% }\end{array}$} \\
\hline & $\begin{array}{l}\text { Number of } \\
\text { Companies }\end{array}$ & $\begin{array}{l}\text { Percent of } \\
\text { Sample,\% }\end{array}$ & $\begin{array}{c}\text { Company } \\
\text { No }\end{array}$ & $\begin{array}{l}\text { Percent of } \\
\text { Sample,\% }\end{array}$ & \\
\hline $0<$ ETR $\leq 10$ & 11 & 5,34 & 14 & 6,79 & 1,46 \\
\hline $10<\mathrm{ETR} \leq 20$ & 73 & 35,43 & 89 & 43,20 & 7,77 \\
\hline $20<\mathrm{ETR} \leq 30$ & 60 & 29,13 & 82 & 39,81 & 10,68 \\
\hline $30<\mathrm{ETR} \leq 40$ & 53 & 25,73 & 16 & 7,77 & $-17,96$ \\
\hline ETR $>40$ & 9 & 4,37 & 5 & 2,43 & $-1,94$ \\
\hline Total & 206 & 100,00 & 206 & 100,00 & - \\
\hline
\end{tabular}

The Degree of Marketization (DOM) of the Provinces

Table 3

\begin{tabular}{|l|l|}
\hline $\begin{array}{l}\text { Degree of } \\
\text { Marketization }\end{array}$ & Province (Arrange from high to low) \\
\hline $\begin{array}{l}\text { Higher } \\
(\mathrm{DOM}=1)\end{array}$ & $\begin{array}{l}\text { Zhejiang, Guangdong, Shanghai, Jiangsu, Fujian, Beijing, } \\
\text { Tianjin, Shandong, Liaoning, Chongqing }\end{array}$ \\
\hline $\begin{array}{l}\text { Lower } \\
(\mathrm{DOM}=0)\end{array}$ & $\begin{array}{l}\text { Anhui, Hebei, Sichuan, Henan, Hubei, Hunan, Hainan, } \\
\text { Jiangxi, Jilin, Guangxi, Heilongjiang, Shanxi, Inner } \\
\text { Mongolia, Yunnan, Shensi, Guizhou, Ningxia, Gansu, } \\
\text { Xinjiang, Qinghai, Tibet }\end{array}$ \\
\hline
\end{tabular}


debts. We expect the coefficient of $Z$ to be negative.

CASH is cash flow, defined as the ratio of net cash flow from operating activities and total assets. On the one hand, Jensen [18], a representative of the trade-off theory, thought that if management has a lot of free cash flow, it is equivalent to the presence of a big «buffer» which can deal with the future possible loss. Therefore, the larger the company's free cash flow was, the higher a financial leverage should have to limit management discretion; On the other hand, Myers [3] proposed peck order theory to argue that, because of information asymmetry, companies with better profitability are prone to low cost internal financing instead of external financing. Accordingly, we expect the sign of $\mathrm{CASH}$ to be uncertain.

UNIQ represents uniqueness. It is computed as the ratio of the sum of selling expenses and R\&D expenses and sales revenue. Timan \& Wessels [16] thought that companies who produce unique products will have lower leverage because it is more difficult for their customers to find substitutes of their service or products. Balakrishman \& Fox (1993) argue that brands, $R \& D$ expenses and other investments in reputation will influence firms' ability. The higher the proportion of intangible assets is, the better the firm's credit level is, and the easier it is for the firm to get loans. We expect the sign of UNIQ to be positive.

IND is a dummy variable for industry. In order to strengthen the international comparability of this paper, unlike the previous researches that followed CSRC's industry classification, we choose the global industry classification system (GICS) launched by standard \& poor's (S\&P) and Morgan Stanley (MSCI) in August 1999. Specifically, we classify the sample companies into 10 industries: energy, raw materials, industrial, consumer discretionary, consumer goods, health care, real estate, information technology, telecommunication services, and utilities. We set up as many as nine dummy variables, so as to observe the industry effect of the debt tax shield.

\section{Empirical results.}

4.1. Descriptive Statistics. Table 4 presents the descriptive statistics and the Pearson correlation matrix for all the variables, from which we can see the statistical characteristics of all the variables and their correlations. The absolute value of the correlation coefficient between any two variables are less than 0,35 , indicating that there is no serious multicollinearity.

The mean (mean, median) of DAR of the sample companies in 2003-2011 is about $50 \%$. For developed countries, due to the limited availability of foreign listed company data, we refer to the approach of Yuancheng $\mathrm{Hu}$ (2008), and only compare with the listed companies that are included in some countries' stock indices in the same period; for developing countries, we use for comparison the DAR data of some developing countries offered in the study of Rajan \& Zingales (2000). The result shows that, for a rather long time, the DAR of Chinese listed companies is low compared to the companies in developed countries, and at the medium level compared to the companies in developing countries. This means that Chinese companies did not make a good use of financial leverage (Table 5).

\subsection{The applicability of $\mathrm{MM}$} theorem. Model (A) in Table 6 partially demonstrates applicability of the MM theorem. Adjusted R2 is 0,3060, which is significant at the $1 \%$ level and indicates that the overall model fits well. The signs of ETR and the cross term is negative, indicating that, in the period of 2008-2011, compared to companies with increased effective tax rates, companies with decreased effective tax rates reduced the proportion of debt financing significantly. This result is in line with the «differential taxation hypothesis». The sign of Year is positive. Due to the increasing emphasis on the leverage governance theory, the overall debt ratios increased in 2008.

As to the control variables, the signs of firm size, bankruptcy risk and uniqueness are in line with expectations. This indicates that a bigger size, a lower bankruptcy risk and more prominent uniqueness will make 
Descriptive Statistics and Pearson Correlation Matrix

Table 4

\begin{tabular}{|c|c|c|c|c|c|c|}
\hline \multicolumn{7}{|c|}{ Panel A: The descriptive statistics } \\
\hline Variable & $\mathrm{N}$ & Minimum & Maximum & Median & Mean & Std \\
\hline DAR & 1648 & 0,0826 & 0,9027 & 0,5122 & 0,5073 & 0,1544 \\
\hline SIZE & 1648 & 8,6787 & 11,6614 & 9,5357 & 9,6093 & 0,4837 \\
\hline $\mathrm{ROA}$ & 1648 & $-0,0051$ & 1,4413 & 0,0350 & 0,0451 & 0,0483 \\
\hline Z & 1648 & 0,0454 & 27,7986 & 0,8344 & 1,0024 & 1,0433 \\
\hline $\mathrm{CASH}$ & 1648 & $-0,3350$ & 0,5526 & 0,0618 & 0,0604 & 0,0850 \\
\hline UNIQ & 1648 & 0,0000 & 0,5158 & 0,0392 & 0,0611 & 0,0722 \\
\hline \multicolumn{7}{|c|}{ Panel B: Correlations } \\
\hline & DAR & SIZE & ROA & Z & $\mathrm{CASH}$ & UNIQ \\
\hline DAR & 1 & - & - & - & - & - \\
\hline SIZE & $0,296^{* *}$ & 1 & - & - & - & - \\
\hline ROA & $-0,341^{* *}$ & 0,044 & 1 & - & - & - \\
\hline Z & $-0,128^{* *}$ & $0,105^{\text {** }}$ & $-0,176^{* *}$ & 1 & - & - \\
\hline CASH & $-0,194^{* *}$ & 0,006 & $0,278^{* *}$ & $-0,019$ & 1 & - \\
\hline UNIQ & $0,244^{* *}$ & $-0,140^{* *}$ & $0,081^{* *}$ & $-0,001$ & $0,055^{*}$ & 1 \\
\hline
\end{tabular}

Note. ${ }^{*},{ }^{* *}$ and ${ }^{* * *}$ denote significant level of $1 \%, 5 \%$ and $10 \%$ (hereinafter the same).

Asset-liability Ratio of Companies in Various Countries

Table 5

\begin{tabular}{|l|c|c|l|}
\hline Index Stock type & DAR, $\%$ & sample & Sample period \\
\hline DAX30 (Germany) & 67 & 24 & 2004.12 .31 \\
\hline CAC40 (France) & 67 & 29 & $2003.12 .31-2004.12 .31$ \\
\hline MIB30 (Italy) & 64 & 14 & $2003.12 .31-2004.12 .31$ \\
\hline AEX25 (Netherland) & 62 & 19 & $2003.12 .31-2004.12 .31$ \\
\hline FTSE100 (UK) & 62 & 51 & $2004.12 .31-2005.12 .31$ \\
\hline Dow Jones Global & 57 & 21 & $2003.12 .31-2004.12 .31$ \\
\hline DJIA (US) & 56 & 24 & 2004.12 .31 \\
\hline KFX20 (Denmark) & 55 & 14 & $2003.12 .31-2004.12 .31$ \\
\hline China & 48 & 1222 & $2003.12 .31-2004.12 .31$ \\
\hline Developing Countries & DAR, \% & sample & \\
\hline Korea & 73 & 93 & $1980-1990$ \\
\hline India & 67 & 93 & $1980-1990$ \\
\hline Pakistan & 66 & 96 & $1980-1987$ \\
\hline Turkey & 59 & 45 & $1983-1990$ \\
\hline China & 50 & 206 & $2003-2011$ \\
\hline Thailand & 49 & 91 & $1983-1990$ \\
\hline Jordan & 47 & 38 & $1983-1990$ \\
\hline Malaysia & 42 & 96 & $1983-1990$ \\
\hline Zimbabwe & 35 & 48 & $1980-1988$ \\
\hline Mexico & 30 & 99 & $1984-1990$ \\
\hline Brazil & & & $1985-1991$ \\
\hline
\end{tabular}


it easier for companies to obtain loans, and result in higher asset-liability ratio. The sign of return on assets and cash flow are negative, which means that companies with better profitability and more free cash flow are more prone to choose lower cost internal financing. This indicates that the relatively conservative «financing Pecking Order Theory» fits better to the actual situation of Chinese listed companies than the trade-off theory. Five controlled variables in Model (A) are significant at the $1 \%$ level, and their signs are in line with expectations.

4.3. Further expansion based on marketization. Considering actual situations in China, we expand our research study of how the degree of marketization influences the debt tax shield effect. Figure 1 shows the number of sample companies in each province in terms of their registered addresses. The numbers of samples in Shanghai and Guangdong are the greatest and account for $14,08 \%$ and $8,74 \%$ of the total sample, respectively. There are more than 10 sample companies in Jiangsu, Beijing, Zhejiang, Shandong and Fujian. These provinces are considered as regions with higher degree of marketization (see Table 2). Tianjin, Chongqing and Liaoning provincearealso included into this group. So, the number of listed companies in the ten regions with a higher degree of marketization makes up $62,69 \%$ of the total sample. If the corporate income tax reform exerted a good effect on companies in these regions, it is proper to say that the reform affects most of the companies.

Empirical Results of Theoretical Assumptions (Mixed Effects Model)

\begin{tabular}{|c|c|c|c|c|}
\hline \multicolumn{2}{|c|}{ Variable } & $\begin{array}{c}\text { Expected } \\
\text { Sign }\end{array}$ & Model (A) & Model (B) \\
\hline \multirow{2}{*}{\multicolumn{2}{|c|}{ C }} & \multirow{2}{*}{$?$} & $-0,3090^{\text {stat }}$ & $-0,5313^{3+*+x}$ \\
\hline & & & $(-4,6066)$ & $(-7,1346)$ \\
\hline \multirow[t]{3}{*}{ DUMMY } & ETR & - & $\begin{array}{l}-0,0146^{* *} \\
(-2,1286)\end{array}$ & $\begin{array}{l}-0,0434^{\text {wat }} \\
(-3,8813)\end{array}$ \\
\hline & DOM & ? & - & $\begin{array}{c}0,0212^{*} \\
(1,8639)\end{array}$ \\
\hline & ETR*DOM & - & - & $\begin{array}{l}-0,0454^{\text {wat }} \\
(-3,2512)\end{array}$ \\
\hline \multirow[t]{5}{*}{ CONTROL } & SIZE & + & $\begin{array}{c}0,0912^{*+*} \\
(13,2073)\end{array}$ & $\begin{array}{c}0,0443^{\text {twat }} \\
(13,9779)\end{array}$ \\
\hline & ROA & ? & $\begin{array}{l}-0,9620^{+40 *} \\
(-13,3114)\end{array}$ & $\begin{array}{l}-0,9465^{\text {nt+ }} \\
(-13,4418)\end{array}$ \\
\hline & $\mathrm{Z}$ & - & $\begin{array}{l}-0.0084^{\text {*ax }} \\
(-2,6185)\end{array}$ & $\begin{array}{l}-0,0150^{\text {not }} \\
(-4,4638)\end{array}$ \\
\hline & CASH & ? & $\begin{array}{l}-0,1818^{\text {that }} \\
(-4,5144)\end{array}$ & $\begin{array}{l}-0,1137^{\text {nat }} \\
(-2,6983)\end{array}$ \\
\hline & UNIQ & + & $\begin{array}{l}0,3774^{*+*} \\
(8,1667)\end{array}$ & $\begin{array}{l}0,2602^{2 *+*} \\
(4,8398)\end{array}$ \\
\hline \multicolumn{3}{|c|}{ Sample Number } & 206 & 206 \\
\hline \multicolumn{3}{|l|}{ Adjusted- $\mathrm{R}^{2}$} & 0,2551 & 0,3099 \\
\hline \multicolumn{3}{|l|}{ F-statistic } & $95,0279^{* \text { twk }}$ & $44,5166^{\text {tate }}$ \\
\hline
\end{tabular}


Model B in Table 6 presents the empirical results of the debt tax shield based on the variance in marketization. The sign of ETR is still negative, indicating that, for companies with decreased ETR, their DARs also decline. The sign of DOM is positive. This shows that, in regions with a higher degree of marketization, the asset-liability ratios are higher and the companies are more willing to use financial leverage. But in regions with a lower degree of marketization, the companies are relatively more conservative and, thus, keep relatively a lower asset-liability ratio. The sign of ETR * DOM is negative, indicating that in regions with a higher degree of marketization, when ETR declines, DAR will decline in sync, and the absolute value of the coefficient $(-0,0454)$ is greater than the absolute value of the ETR coefficient $(-0,434)$. This demonstrates Hypothesis 3: when the degree of marketization is higher, the adjustment of the capital structure is more sensitive to the change of debt tax shield and the tax planning is more radical. Since the number of listed companies in regions with a high degree of marketization makes up a majority of the total sample, we can conclude that this reform is effective. What's more, the sign of control variables are consistent with expectations and are significant at the level of $1 \%$
Figure 2 presents the relationship of degree of marketization, effective tax rate and asset-liability ratio. In the two lines where ETR $=1$ (falling), the companies whose $\mathrm{DOM}=1$ (with a higher degree of market) has a more significant decline in 2006-2008 than companies whose $\mathrm{DOM}=0$. This is also true when ETR rises. This further demonstrates the conclusion that the higher the degree of marketization is, the more obvious the debt tax shield effect is. Besides, we also find that the asset-liability ratios of all the companies increased, showing that Chinese companies are narrowing the gap against companies in developed countries in the usage of financial leverage.

Since both the corporate income tax and the degree of marketization affect the capital structure, we would like to know whose effect is more significant. Using ETR and DOM as dummy variables, we conduct univariate regression to see whether the explanation of ETR and DOM is significant. The result is shown in Table 7. The corporate income tax (ETR) is significant at the level of $10 \%$ and the degree of marketization (DOM) is significant at the level of $1 \%$. The explanation proportion of ETR's and DOM to asset-liability ratio is 0,0011 and 0,0058 , respectively. The analysis shows that, compared with the effective tax rate, the degree of marketization is

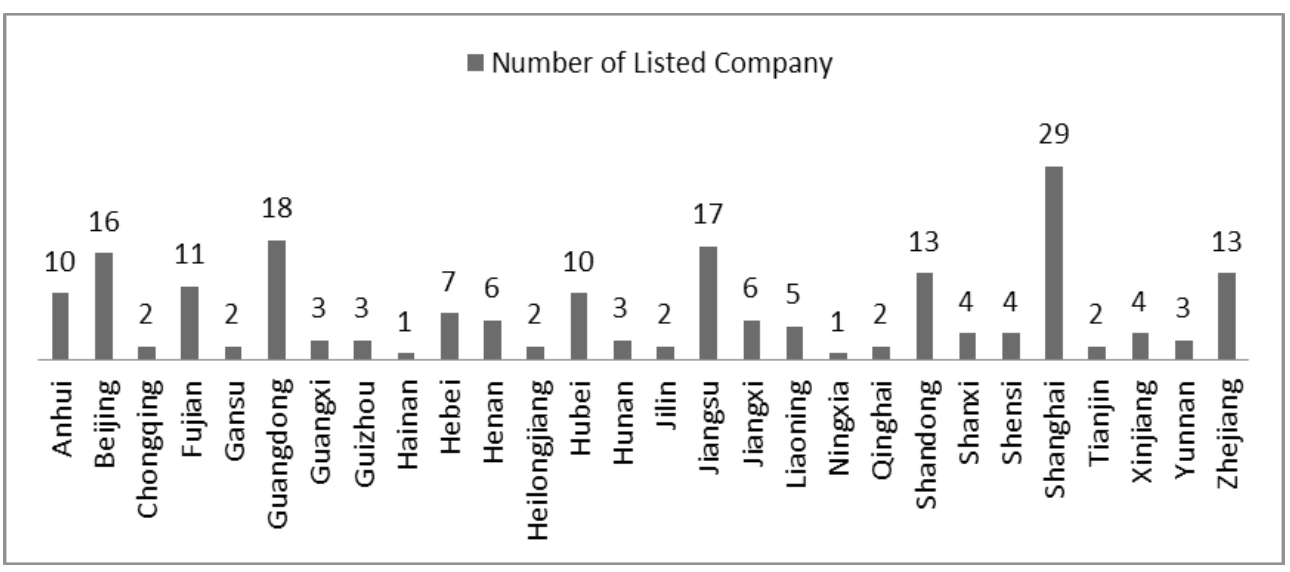

Figure 1. Number of Sample Companies Based on Registered Address 
more significant in influencing the capital structure.

4.4. Debt tax shield effect on capital structure at industrial level. Referring to GICS (Global Industry Classification Standard) $)^{5}$, we divide the sample companies into several sectors, as is shown in Table 8 . Table 8 presents the ranking of ETR and DAR and their changes before and after the reform.

According to GICS, the composition of each section is as follows: industrial includes capital goods, commercial \& professional service, and transportation; consumer discretionary includes automobiles and components, consumer durables and apparel, consumer service, media and retailing; consumer goods include food and staples retailing, food, beverages \& tobacco, household and personal products; health care includes health care equipment \& services, pharmaceuticals, biotechnology \& life sciences; information technology includes software \& services, technology hardware \& equipment and semiconductor sand semiconductor equipment. The other sectors only include one industry in them.
From the perspective of ETR, we find that industries related to public well-fare such as utilities and consumer goods assume lower tax burden, while manufacturing industries such as consumer discretionary and materials take heavier tax burden. From the perspective of DAR, we find that real estate industry shows an apparent reliance on leverage and has the highest asset-liability ratio and the highest risk, while public well-fare industries such as utilities and consumer goods and hightech industries such as health care and information technology have relatively low debt ratios. From the perspective of the changes in ETR and DAR, ETR of most of industries declined, although ETR of telecom services, energy and utilities rose due to the cancellation of tax incentive policies to them. In addition, health care and information technology show adverse movements compared to other industries in DAR because the «Three New» incentive policy was still in effect. The debt tax shield effect is relatively not significant.

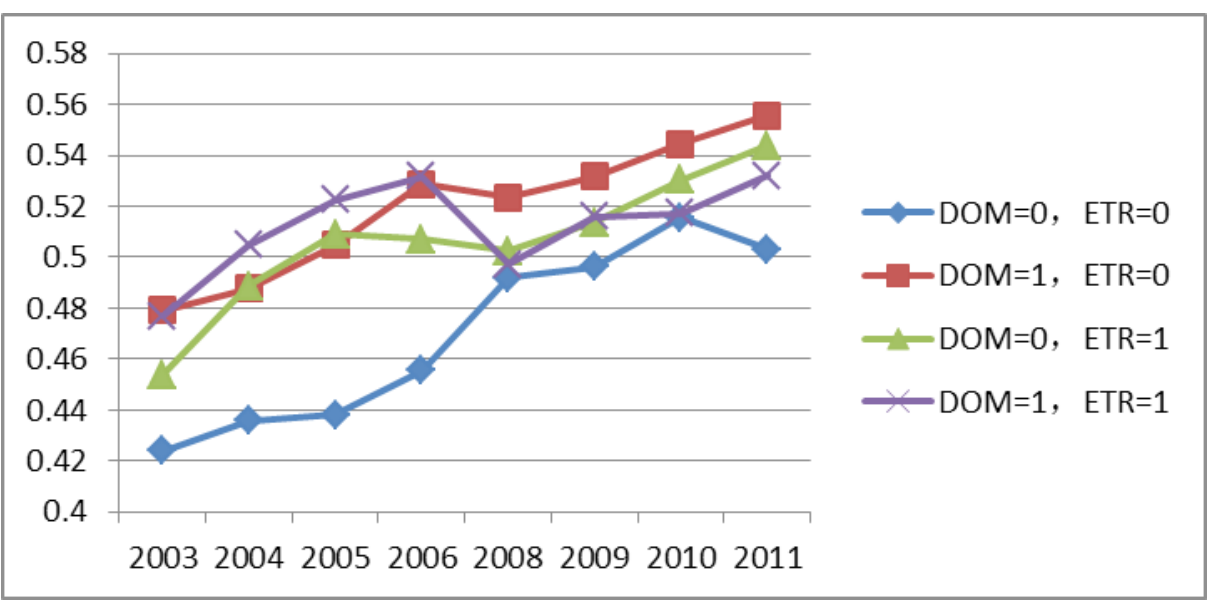

Figure 2. Marketization, ETR and Asset-liability Ratio

ETR\&DOM Univariate Regression

\begin{tabular}{|c|c|c|c|}
\hline Variables & C & $\mathrm{t}$ & Adjusted $^{2}$ \\
\hline ETR & $-0,0192^{*}$ & $-1,7018$ & 0,0011 \\
\hline DOM & $0,0364^{*+*}$ & 3,2696 & 0,0058 \\
\hline
\end{tabular}


Finally, weanalyze theindustry's effect in terms of the debt tax shield on the capital structure. Table 9 presents the results. Most of the sectors have an significant effect on DAR, except for consumer goods whose $P$ value is relatively higher. Health care and information technology industry are significant at the level of $10 \%$, the rest of the industries are significant at the level of $1 \%$. The reason that consumer goods industry is less significant may be that there are rigid market demands on industries related to public well-fare, which attract governmental care in regard of on these industries. Healthcare and information technology industries are relatively not significant because their high technology arouses preferential tax policies. In terms of signs, the negative sign of the telecommunications industry may be of interest because there is only one company in the sample (600050: China Unicom). The sign of the other industries are positive showing that Chinese companies' debt ratio has increased overall. This, on the one hand reflects the improved ability of Chinese companies to use financial leverage, and, on the other hand, indicates that Chinese companies' face increasing operating risks.

Table 8

Ranking of Sample companies' ETR and DAR Before and After the Reform

\begin{tabular}{|l|c|c|c|c|c|c|c|c|}
\hline \multirow{2}{*}{ Industry } & \multirow{2}{*}{$\begin{array}{c}\text { Number of } \\
\text { company }\end{array}$} & \multirow{2}{*}{$\begin{array}{c}\text { Percent, } \\
\%\end{array}$} & \multicolumn{2}{c|}{$\begin{array}{c}\text { Ranking } \\
\text { before Reform }\end{array}$} & \multicolumn{2}{c|}{$\begin{array}{c}\text { Ranking after } \\
\text { Reform }\end{array}$} & \multicolumn{3}{c|}{$\begin{array}{c}\text { Ranking of } \\
\text { Change from } \\
\text { Reform }\end{array}$} \\
\cline { 4 - 10 } & & & ETR & DAR & ETR & DAR & $\Delta$ ETR & $\Delta$ DAR \\
\hline Energy & 9 & 4,37 & 2 & 3 & 8 & 5 & 9 & 9 \\
\hline Materials & 37 & 17,96 & 8 & 9 & 5 & 8 & 4 & 5 \\
\hline Industrial & 44 & 21,36 & 4 & 8 & 4 & 7 & 6 & 6 \\
\hline $\begin{array}{l}\text { Consumer } \\
\text { discretionary }\end{array}$ & 47 & 22,82 & 10 & 7 & 9 & 9 & 5 & 8 \\
\hline $\begin{array}{l}\text { Consumer } \\
\text { goods }\end{array}$ & 12 & 5,83 & 3 & 2 & 1 & 2 & 1 & 7 \\
\hline Health care & 17 & 8,25 & 9 & 1 & 6 & 1 & 2 & 1 \\
\hline Real estate & 22 & 10,68 & 6 & 10 & 3 & 10 & 3 & 4 \\
\hline $\begin{array}{l}\text { Information } \\
\text { technology }\end{array}$ & 10 & 4,85 & 5 & 5 & 7 & 3 & 7 & 2 \\
\hline Telecom & 1 & 0,49 & 7 & 6 & 10 & 4 & 10 & 3 \\
\hline Utilities & 7 & 3,40 & 1 & 4 & 2 & 6 & 8 & 10 \\
\hline
\end{tabular}

Industry Effect according to MM Theorem

\begin{tabular}{|c|c|c|}
\hline Industry & Model (A) & Model (B) \\
\hline Energy & $0,0556^{*+1+1}(2,3648)$ & $0,0487^{7 * *}(2,0641)$ \\
\hline Materials & $0,0790^{4 * *+}(4,1846)$ & $0,0810^{4 *+1+(4,2714)}$ \\
\hline Industrial & $0,0872^{*+* x}(4,5952)$ & $0,0904^{*+* * *}(4,7715)$ \\
\hline Consumer discretionary & $0,1218^{* * * *}(6,3976)$ & $0,1245^{*+* * *}(6,5594)$ \\
\hline Consumer goods & $0,0353(1,5592)$ & $0,0378^{*}(1,6735)$ \\
\hline Health care & $0,0447^{* * *}(1,9769)$ & $0,0425^{*}(1,8824)$ \\
\hline Real Estate & $0,1273^{\text {wate }}(6,2435)$ & $0,1308^{*+* x+}(6,4189)$ \\
\hline Information Technology & $0,0403^{*}(1,7476)$ & $0,0441^{*}(1,9175)$ \\
\hline Telecom & $-0,1796^{*+10}(-3,3514)$ & $-0,1631^{+4+4}(-3,0496)$ \\
\hline
\end{tabular}


4.5. Robustness tests. In order to test the stability of the above conclusions, we make the following robustness tests: in Model (A) and Model (B) we use the liability growth rate, the interest-bearing debt ratio and the interest-bearing debt growth rate as the explaining variables. With the same two-stage least squares method, we get the same conclusion.

There is a big difference in the number of sample companies in each province. For example, the number of sample companies is the largest in the location of the two stock exchanges (Shanghai Stock Exchange and Shenzhen Stock Exchange), but the number of sample companies is small in provinces with the least degree of marketization, such as Ningxia, Qinghai, etc. We think that some of the companies may operate in locations other than their registered address to reduce transaction costs and expand the sources of information. In that case, we exclude sample companies from Shanghai and Guangdong in robustness test to solve the problem. We draw the same conclusion.

The above tests show that the conclusions of this study are robust and reliable. The test results are not listed here to limit the length of the paper.

\section{Conclusions and Suggestions}

Based on the 2008 Enterprise Income Tax Reform in China, this paper explores the influence of exogenous changes of the enterprise income tax rate on the capital structure. The empirical results demonstrate our hypotheses. First, the exogenous change of the enterprise income tax rate would affect the capital structure, and ETR is positively correlated to debt financing. Second, the higher the degree of regional marketization is, the more sensitive the listed companies in that jurisdiction are to the tax shield effect and the more radical their tax planning is. Third, compared to the change of the enterprise income tax rate, differences in degree of marketization exert a more significant effect on corporate capital structure. The explanation of the former is 0,0011 and the explanation of the latter is 0,0058 . Fourth, because of the long- term existence of tax incentives, the debt tax shield is not significant in consumer goods, health care and information technology industries. Fifth, the assetliability ratios of Chinese listed companies is in a rising trend. While this reflects the improving abilities of those companies to use financial leverage, it also shows the deterioration of their operating risks.

Policy suggestions are as follows:

1. Foster market reform. In eastern coastal provinces and municipalities where the degree of marketization is higher, the adjustment of the enterprise capital structure is more sensitive to the exogenous tax reform, and the tax planning is more radical. In addition, the degree of marketization exerts a more significant effect on capital structure than the change of the corporate income tax rate does. In order to guarantee the effectiveness of the reform, China should take an effort to improve the marketization level of the less developed provinces. In terms of taxes, this includes reducing companies' tax burden, increasing transparency of tax collection and management, etc.

2. Different tax incentives in different industries. Regional tax incentives may result in company moves to avoid tax and inefficient operation. We have found the industry effect in this paper, so the debt tax shield effect is significant in most industries, especially in industrial enterprises, but not significant in industries such as public well-fare industries and high-tech industry, where tax incentives exist. So, preferential tax policies could be used to support development of key enterprises and growth of specific industries.

3. Keep reasonable level of liabilities. In recent years, the asset-liability ratios of Chinese listed companies have ben rising. On the one hand, this reflects that Chinese companies' ability of using financial leverage is closer to that of the companies in developed countries. On the other hand, this also implies an increasing operating risk. Therefore, companies cannot expand debt financing blindly to achieve, a maximized debt tax shield. They should take into account the risks and keep a reasonable debt level. 


\section{Reference}

1. Modigliani F., Miller M. H. Corporation Income Taxes and the Cost of Capital: A Correction. American Economic Review, 1963, vol. 53, no. 3, pp. 433-443.

2. Miller M. H. Debt and Taxes. Journal of Finance, 1977, vol. 32, no. 2, pp. 261-275.

3. Myers S., Majluf N. S. Corporate Financing and Investment Decisions when Firms have Information that Investors do not have. Journal of Financial Economics, 1984, vol. 13, no. 2, pp. 187-221.

4. MacKie-Mason J. K. Do Taxes Affect Corporate Financing Decisions? Journal of Finance, 1990, vol. 45, no. 5, pp. 1471-1493.

5. Givoly D., Hayn C., Ofer A. R., Sarig O. Taxes and Capital Structure: Evidence from Firmsp Response to Tax Reform Act of 1986. Review of Financial Studies, 1992, vol. 5, no. 2, pp. 331-355.

6. Rajan R. G., Zingales L. What do we know about capital structure? Some evidence from international data. The Journal of Finance, 1995, vol. 50, no. 5, pp. 1421-1460.

7. Fang J. Ownership, Institutional Environment and Capital Allocation. Economic Research Journal, 2007, no. 12, pp. 82-92.

8. Jiang Wei, Li Bin. Institutional Environment, State-owned Property and Bank Lending Discrimination. Journal of Financial Research, 2008, no. 11, pp.116-126.

9. Yu Minggui, Pan Hongbo. Government Intervention, Development of Law and Finance, and Bank Loan for State-owned Enterprise. Journal of Financial Research, 2008, no. 9, pp. 1-22.

10. Kornai J. Economics of Shortage. Amsterdam, North-Holland Press, 1980.

11. Lin Yifu, Liu Mingxing, Zhang Qi. Policy Burden and Enterprise's Soft Budgetary Binding: a Case Study from China. Management World, 2004, no. 8, pp. 81-89.

12. Sun Zheng, Liu Fengwei, Li Zengquan. Market Development, Government Influence and Corporate Debt Maturity Strucure. Economic Research Journal, 2005, no. 5, pp. 52-63.

13. Fuxiu Jiang, Jicheng Huang. The Process of Market-oriented and the Dynamic Adjustment of Capital Structure. Management World, 2011, no. 3, pp. 124-134.

14. Wang Yuetang, Wang Lianglian, Peng Yang. Ownership Nature of Ultimate Controller, Debt-related Tax Shields and Capital Structure. Economic Research Journal, 2010, no. 9, pp. 122-136.

15. Wang Yanming. Sensitivity Analysis of Income Tax Rate Changes On Listed Company. Economic Research Journal, 2002, no. 9, pp.74-80.

16. Titman S., Wessels R. The Determinants of Capital Structure Choice. The Journal of Finance, 1988, vol. 43, no. 1, pp. 1-19.

17. Graham J. R. Debt and the Marginal Tax Rate. The Journal of Financial Economics, 1996, no. 41, iss. 1, pp. 41-74.

18. Jensen M. C. Agency Costs of Free Cash Flow, Corporate Finance and Takeovers. American Economic Review, 1986, vol. 76, no. 2, pp. 323-329.

\section{Author}

Yong Fan - Professor, Vice Dean of School of Taxation, Director of Business Taxation Center, Central University of Finance and Economics (CUFE), (39 South College Road Haidian District, Beijing, e-mail: yongfan008@sina.com or fanyong@cufe.edu.cn)

\section{Информация об авторах}

Юн Фань - Профессор, Заместитель декана факультета налогообложения, Директор Центра налогообложения бизнеса, Центральный Университет Финансов и Экономики, г. Пекин, Китай (г. Пекин, район Хэйдайэн, ул. Саус Колледж, 39, e-mail: yongfan008@sina.com; fanyong@cufe.edu.cn) 